Nig J. Biotech. Vol. 31 (2016) $40-45$

ISSN: 01891731

Available online at

http://www.ajol.info/index.php/njb/index

and www.biotechsocietynigeria.org

DOI: http://dx.doi.org/10.4314/njb.v31i1.6

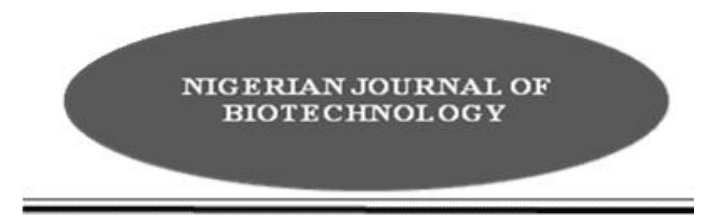

\title{
Antibiotic Sensitivity Pattern of Microorganisms I solated from Smoked and Frozen Fishes Sold in Benin and Warri Metropolis
}

\author{
I marhiagbe, E.E. ${ }^{1}$, Ofuya, M.E. ${ }^{2}$, Osarenotor, $0 .{ }^{3}$ and Ekhaise, F.O. ${ }^{4}$ \\ ${ }^{1,3}$ Department of Environmental Management and Toxicology, Faculty of Life Sciences, University of \\ Benin, Benin City. ${ }^{2}$ Department of Science Laboratory Technology, Faculty of Life Sciences, University \\ of Benin, Benin City. ${ }^{4}$ Department of Microbiology, Faculty of Life Sciences, University of Benin, Benin
} City.

(Received: 12:07:2016; Accepted: 25:07:2016)

\begin{abstract}
Antibiotic sensitivity pattern of microorganisms isolated from smoked and frozen fishes sold in Benin and Warri metropolis were investigated. Adopting microbiological standard techniques, the results of the bacterial counts and fungal counts ranged from $5.4 \times 10^{6}$ (Ekpan market) to $25.1 \times 10^{6}$ (Ekpan market) and $1.1 \times 10^{5}$ (Ekpan and New Benin market) to $2.9 \times 10^{5}$ (Effurun market). Six bacterial species namely; Staphylococcus spp., Escherichia coli, Bacillus spp., Pseudomonas sp., Corynebacterium sp., Micrococcus sp. and four fungal species namely; Aspergillus spp., Fusarium sp., Mucor sp. and Penicillium spp. were identified. Majority of the bacteria were isolated from fish samples from Benin City Markets $(51.1 \%, n=23)$ while $(48.9 \%, n=22)$ were obtained from Warri Markets. Bacillus spp. were the most predominant (35.6 \%) and Micrococcus sp. was the least predominant among the bacterial isolates (2.2\%). Aspergillus sp. was recorded the most predominant $(37.1 \%)$ while Penicillium sp. $(14.3 \%)$ was the least predominant among the isolated fungi. The isolated bacteria (Escherichia coli, Bacillus sp., Staphylococcus sp., Pseudomonas sp., Corynebacterium sp. and Micrococcus sp.) were sensitive to ciprofloxacin and showed resistance to zinnacef and rocephin. These findings show that fish samples from different markets harbour varied levels of potentially pathogenic organisms which could pose health threat to consumers. Proper handling, processing and storage methods should be put in place to reduce potential health risk.
\end{abstract}

Keywords: fishes, bacterial and fungal, isolates, antibiotic

Correspondence: esosa.imarhiagbe@uniben.edu

\section{Introduction}

Fishes are known to be highly nutritious and excellent sources of animal protein, which is consumed by a larger percentage of the world's population because of its availability and palatability (Foran et al., 2005; Sutharshiny and Sivashanthini, 2011). Marketing of fish in Nigeria is mostly carried out by local fish sellers (Okoro et al., 2010), hence it's harvesting, handling processes and distribution provides livelihood for millions of people. Fish flesh contains significantly low lipid and high water compared to that of beef or chicken (Nestel, 2000) and rich in vitamins and minerals for both young and old consumers (Edem, 2009; Koffi-Nevny et al., 2011).

Contamination of fish and other fish products by microbes have been a serious threat to human health. The improper handling and storage processes of fish pose serious effects thereby limiting the shelf life of the products (Sallam, 2007). The quality of fish products degrades due to complex processes in which physical, chemical and micro-biological forms are implicated (Sallam, 2007). Doyle (2007) had reported that storage and processing conditions affect microbial growth. Thus the need for proper handling, storage facilities and the knowledge of spoilage pattern at tropical fishes and their shelf life under ambient condition is very imperative (Okoro et al., 2010).

The smoking of fish from smoldering wood for its preservation dates back to civilization (Olokor, 2007). It's also noted that apart from giving the product a desirable taste and odour, smoking provides longer shelf life through its anti-bacterial and oxidative effect, lowering of $\mathrm{pH}$, imparting, desirable coloration 
as well as accelerating the drying process and acting as antagonist to spoilage agents (Sengor et al., 2004; Eyo, 2001; Homer, 1997). Martin (1994) stated that organisms such as Staphylococcus aureus, Saccharomyces cerevisiae, Penicillium and Aspergillus were the commonest microorganisms associated with smoked fish. Freezing is a widely used method for the preservation of fish which involve the use of refrigeration, cold rooms and icing etc. Freezing generally slows down the deterioration of fish at low storage temperature (Sivertsvik et al., 2002).

The aim of this study was to investigate the microbiological qualities and antibiotic sensitivity pattern of the isolated bacteria from smoked and frozen sold in markets in BeninCity and Warri.

\section{Materials and methods}

Collection of samples: Smoked and frozen fish samples were obtained from two different Markets in Warri (Ekpan and Effurun Markets) and Benin City (Uselu and New-Benin Markets). The fish samples were collected in labelled aseptic containers and transported to the laboratory for analysis.

Enumeration and isolation of microbial isolates: Ten grams of fish sample was weighed into $90 \mathrm{ml}$ of sterilized peptone water for serial dilutions processes $\left(10^{-4}\right.$ and $\left.10^{-5}\right)$ were prepared and used for serial dilution. Appropriate dilutions were plated in duplicates on sterile nutrient agar and potato dextrose agar for total heterotrophic bacterial and fungal counts respectively. The PDA agar plates were made selective for fungal growth by the addition of $1 \mathrm{ml}$ of $250 \mathrm{mg} / \mathrm{ml}$ chloramphenicol solution prior to pouring of the molten medium. The agar plates were incubated aerobically at $30{ }^{\circ} \mathrm{C}$ for 48 hours and 5 days at room temperature $\left(28^{\circ} \mathrm{C} \pm 5^{\circ} \mathrm{C}\right)$ for total heterotrophic bacterial and total fungal counts respectively. After incubation, counts obtained were recorded and expressed as the colony forming unit per gram ( $\mathrm{cfu} / \mathrm{g}$ ) of the original sample (Harley and Prescott, 2002). The various isolates were further identified and characterized using the methods of Barnett and Hunter, 1975; Cheesbrough, 2006.

Antibiotic Sensitivity Testing: Antibiotics sensitivity patterns of the bacterial isolates were determined using the disc diffusion method (Cheesbough, 2003). The discs were placed on Muller-Hinton agar plates that were seeded with the broth culture of the test organisms. The plates were inverted and left on the work bench for 30 min to allow for diffusion of antibiotics into the agar, this was followed by incubation at $37^{\circ} \mathrm{C}$ for $48 \mathrm{hr}$, after which zones of inhibition were examined and interpreted using standard charts (NCCLS, 2003).

\section{Results}

Table 1 shows the total bacterial and total fungal counts of fish samples from Markets in Warri and Benin City. The bacterial count ranged from $5.4 \times 10^{6}$ (Ekpan market) to 25.1 $x 10^{6}$ (Ekpan market) while the fugal counts ranged from $1.1 \times 10^{5}$ (Ekpan and New Benin market) to $2.9 \times 10^{5}$ (Effurun market).

Table 1: Total viable count for bacterial and fungal isolate

\begin{tabular}{lllll}
\hline Markets & $\begin{array}{l}\text { Smoked Fish } \\
\text { Total } \\
\text { Counts Cfu/g }\end{array}$ & $\begin{array}{l}\text { Bacterial } \\
\text { Total Fungal counts }\end{array}$ & $\begin{array}{l}\text { Frozen Fish } \\
\text { Total } \\
\text { Counts Cfu/g }\end{array}$ & $\begin{array}{l}\text { Bacterial } \\
\text { Cful }\end{array}$ \\
\hline EKM & $5.4 \times 10^{6}$ & $2.0 \times 10^{5}$ & $23.2 \times 10^{6}$ & $\begin{array}{l}\text { Total Fungal } \\
\text { counts } \\
\text { Cfu/g }\end{array}$ \\
EKM & $7.0 \times 10^{6}$ & $1.1 \times 10^{5}$ & $25.1 \times 10^{6}$ & $1.2 \times 10^{5}$ \\
EKM & $9.1 \times 10^{6}$ & $3.0 \times 10^{5}$ & $19.0 \times 10^{6}$ & $1.8 \times 10^{5}$ \\
EFM & $10.4 \times 10^{6}$ & $4.4 \times 10^{5}$ & $18.2 \times 10^{6}$ & $2.9 \times 10^{5}$ \\
EFM & $9.2 \times 10^{6}$ & $2.3 \times 10^{5}$ & $17.2 \times 10^{6}$ & $1.8 \times 10^{5}$ \\
EFM & $8.4 \times 10^{6}$ & $1.7 \times 10^{5}$ & $21.6 \times 10^{6}$ & $1.3 \times 10^{5}$ \\
USM & $7.0 \times 10^{6}$ & $2.3 \times 10^{5}$ & $16.8 \times 10^{6}$ & $1.8 \times 10^{5}$ \\
USM & $5.6 \times 10^{6}$ & $1.40 \times 10^{5}$ & $9.8 \times 10^{6}$ & $1.3 \times 10^{5}$ \\
USM & $8.1 \times 10^{6}$ & $1.70 \times 10^{5}$ & $8.8 \times 10^{6}$ & $2.1 \times 10^{5}$ \\
NBM & $4.4 \times 10^{6}$ & $1.3 \times 10^{5}$ & $11.6 \times 10^{6}$ & $1.6 \times 10^{5}$ \\
NBM & $6.4 \times 10^{6}$ & $1.1 \times 10^{5}$ & $20.8 \times 10^{6}$ & $1.4 \times 10^{5}$ \\
NBM & $7.2 \times 10^{6}$ & $1.5 \times 10^{5}$ & $8.0 \times 10^{6}$ & $1.7 \times 10^{5}$ \\
\hline
\end{tabular}

KEY: $\mathrm{EKM}=$ Ekpan market, $\mathrm{EFM}=$ Effurun market,

$\mathrm{USM}=$ Uselu market, NBM $=$ New Benin market 
Table 2 shows the percentage frequency of occurrence of bacterial isolates obtained from the fish samples bought from markets in Warri and Benin City respectively. The result shows that Bacillus $\mathrm{sp}$. was the most predominant $(35.6 \%)$ followed by Staphylococcus $(31.1 \%)$, Escherichia coli $(17.8 \%)$, Pseudomonas sp. $(8.9 \%)$,
Corynebacterium sp. $\quad(4.4 \quad \%)$ and Micrococcus sp. was the least predominant among the bacterial isolates (2.2\%). Majority of the bacteria were isolated from fish samples from Benin City Markets $(51.1 \%, \mathrm{n}$ $=23)$ while $(48.9 \%, n=22)$ were obtained from Warri Markets.

Table 2: Percentage frequency of occurrence of bacterial isolates

\begin{tabular}{lccc}
\hline & & \multicolumn{2}{c}{ Market Locations (\%) } \\
\multicolumn{1}{c}{ Isolate } & No (\%) & Warri (\%) & Benin (\%) \\
\hline Bacillus spp. & $16(35.6)$ & $8(36.4)$ & $8(34.8)$ \\
Staphylococcus spp. & $14(31.1)$ & $6(27.3)$ & $8(34.8)$ \\
E. coli & $8(17.8)$ & $4(18.2)$ & $4(17.4)$ \\
Pseudomonas sp. & $4(8.9)$ & $3(13.6)$ & $1(4.4)$ \\
Corynebacterium sp. & $2(4.4)$ & $1(4.5)$ & $1(4.4)$ \\
Micrococcus sp. & $1(2.2)$ & $0(0.0)$ & $1(4.4)$ \\
Total & $45(100)$ & $22(48.9)$ & $23(51.1)$ \\
\hline
\end{tabular}

Table 3 shows the percentage frequency occurrence of fungal isolates from this study. Aspergillus sp. was recorded the most predominant $(37.1 \%)$ while Penicillium $\mathrm{sp}$. $(14.3 \%)$ was the last predominant among the isolated fungi. The results of the antibiotic sensitivity pattern of bacterial isolates are shown in Table 4. The inhibitory zones of antibiotic resistance and sensitivity $(\mathrm{mm})$ revealed variable antibiogram patterns of the tested isolates. The isolated bacteria (Escherichia coli, Bacillus sp., Staphylococcus sp., Pseudomonas sp., Corynebacterium sp. and Micrococcus sp.) in this study were sensitive to ciprofloxacin and showed resistance to zinnacef and rocephin.

\section{Discussion}

The presence of microorganisms in fishes is not out of place, when viewed as a variable substrate for the proliferation of these organisms. However, when considered from the public health stand point, growth and presence of microorganisms in commercially sold smoke and frozen fishes is unacceptable. The results of this study demonstrated the significant presence of saprophytic and pathogenic microbial flora in commercially sold smoked and frozen fishes from major Markets in Benin City and Warri.

The isolated microbial isolates included six bacterial and four fungal isolates. They were Staphylococcus spp., Bacillus spp., Pseudomonas sp., Micrococcus sp., Escherichia coli, Corynebacterium sp.,
Aspergillus spp., Fusarium spp., Penicillium spp., and Mucor sp.

The presence and high number of these microbial genera could be explained by the fact that these organisms can withstand the adverse processing conditions. These bacterial and fungal isolates have earlier been implicated as major pathogens associated with fish spoilage (Gram and Huss, 2001). According to Adebayo-Tayo et al. (2011), contamination of fish may occur from food handlers and retailers who sell these items to the public for consumption. Bacillus sp. and Aspergillus sp. had the highest frequency of occurrence among the various bacterial and fungal isolates which may have been occasioned by poor handling or cross contamination (Gupta et al., 2006). Also, organisms like Bacillus and fungal genera such as Aspergillus and Penicillium spp. were reported to survive for a long time in a dormant state due to the spore forming state.

The presence of indicator organisms like Escherichia coli might be as a result of possible contamination during sales and unhygienic handling of fish products. The isolation of Pseudomonas sp. from the fish samples is of high importance because it plays a considerable role as a potential pathogenic bacteria for human, also as an indicator of food quality and as a good spoilage index (J eyesekaran et al., 2006; Yagoub, 2009), and it was prevalent in the fish sampled from Warri market. 
Table 3: Percentage frequency of occurrence of fungal isolates

\begin{tabular}{llll}
\hline & & \multicolumn{2}{l}{ Market Locations (\%) } \\
\cline { 3 - 4 } Isolate & No $(\%)$ & $7(38.9)$ & Benin (\%) \\
\hline Aspergillus spp. & $13(37.1)$ & $6(33.3)$ & $6(35.3)$ \\
Fusarium spp. & $10(26.6)$ & $2(11.1)$ & $4(23.5)$ \\
Mucor sp. & $7(20.0)$ & $3(16.7)$ & $5(29.4)$ \\
Penicillium spp. & $5(14.3)$ & $18(51.4)$ & $2(11.8)$ \\
Total & $35(100)$ & $17(48.6)$ \\
\hline
\end{tabular}

Table 4: Antibiotics Sensitivity Test Result

\begin{tabular}{lllllll}
\hline Antibiotic & \multicolumn{7}{c}{ Test Isolate } \\
\cline { 2 - 7 } & $\begin{array}{l}\text { Escherichia } \\
\text { coli }\end{array}$ & $\begin{array}{l}\text { Bacillus } \\
\text { sp. }\end{array}$ & $\begin{array}{l}\text { Staphylococcus } \\
\text { sp. }\end{array}$ & $\begin{array}{l}\text { Pseudomonas } \\
\text { sp. }\end{array}$ & $\begin{array}{l}\text { Corynebacterium } \\
\text { sp. }\end{array}$ & $\begin{array}{l}\text { Micrococcus } \\
\text { sp. }\end{array}$ \\
\hline PEF & $12 \mathrm{~mm}$ & Nil & Nil & $14 \mathrm{~mm}$ & $17 \mathrm{~mm}$ & Nil \\
CN & $12 \mathrm{~mm}$ & Nil & Nil & $7 \mathrm{~mm}$ & $15 \mathrm{~mm}$ & Nil \\
APX & $8 \mathrm{~mm}$ & Nil & Nil & Nil & Nil & $11 \mathrm{~mm}$ \\
Z & Nil & Nil & Nil & Nil & Nil & $10 \mathrm{~mm}$ \\
AM & $10 \mathrm{~mm}$ & Nil & Nil & Nil & Nil & Nil \\
R & Nil & Nil & Nil & Nil & Nil & Nil \\
CPX & $9 \mathrm{~mm}$ & $13 \mathrm{~mm}$ & $16 \mathrm{~mm}$ & $9 \mathrm{~mm}$ & $11 \mathrm{~mm}$ & $9 \mathrm{~mm}$ \\
S & $11 \mathrm{~mm}$ & Nil & Nil & Nil & Nil & $10 \mathrm{~mm}$ \\
SXT & $10 \mathrm{~mm}$ & Nil & Nil & Nil & Nil & Nil \\
E & Nil & Nil & Nil & $12 \mathrm{~mm}$ & $16 \mathrm{~mm}$ & $7 \mathrm{~mm}$ \\
\hline
\end{tabular}

KEY: PEF = Perfloxacin, $C N=$ Gentamycin, $A P X=$ Ampiclox,$Z=$ Zinnacef, $A M=$ Amoxacilin, $\mathrm{R}=$ Rocephin,

CPX = Ciprofloxacin, $\mathrm{S}=$ Streptomycin, SXT = Septrin, E = Erythromycin, Nil = no zone of inhibition

Staphylococcus sp. produce a variety of extra cellular enzymes and toxins that have been found to be responsible for food poisoning and can rapidly develop resistance to many anti-microbial agents and pose a therapeutic problem. Aspergillus sp. and related mould generally grow faster and are more resistance to high temperature and low water activities and tends to dominate spoilage in warmer climate (Doyle, 2007).

Ogunshe and Olabode (2009) reported antibiotic resistance among bacterial species isolated from the fish (Clarias gariepinus). According to Malik and Ahmad (1994), high levels of bacterial resistance to antibiotics are indications of abuse and misuse of antibiotics in the society. This involves situation where individuals purchase and consume antibiotics with out and medical advice. Bacterial groups co-habiting a common environment may express a similar antibiotics pattern if they share in a common pool of R-factor plasmids (Spanggard et al., 1993). All isolates were sensitive to ciprofloxacin and showed resistance to rocephin and zinnacef except Micrococcus sp.
This study therefore confirms the presence of some pathogenic bacterial and fungal isolates from the frozen and smoked fish which are of public health significance and indicative of health risk in contacting diseases associated with these organisms. Compliance with standard microbiological measures to prevent contamination by these organisms becomes very necessary and should be enforced.

\section{References}

Adebayo-Tayo, B.C., Okonko, I.O., Esen, C.U., Odu, N.N., Onoh, C.C. and Igwuiloh, N.J.P. (2011). Incidence of potentially pathogenic vibro spp in fresh seafood from its creek in Uyo, Akwa Ibom State, Nigeria. World Applied Science Journal, 15(7): 985 991.

Barnett, H. L. and Hunter, B. B. (1975). Illustrated Genera of Imperfect Fungi. $3^{\text {rd }}$ Edn. Burgess, New York, 225 pp.

Cheesbrough, M. (2006). District Laboratory Practices in Tropical Countries. Cambridge University Press, UK. 416pp. 
Doyle, E.M. (2007). Microbial food spoilage losses and control strategies. A brief review of the literature. Food Research Institute, University of Wesconson-Madison.

Edem, D.O. (2009). Vitamin A. A review. Asian J ournal of Clinical Nutrition. 1:65-82.

Eyo, A.A (2001). Fish Processing Technology in Tropics. National Institute for Fresh water Fisheries Technology, New Bussa, Nigeria. pp154-160.

Foran, J.A., carpenter, D.D., Hamlton, M.C., Knuth, B.A. and Schwager, S.J. (2005). Risk based consumption advice for farmed Atlantic and wild pacific salmon contaminated with dioxin and dioxin-like compound. Environmental Health Perspective, 33: 350356.

Gram, L. and Huss, H.H. (2001). Microbiological spoilage of fish and fish products. International Journal of Food Microbiology, 33: 121 - 137.

Gupta, S. (2006). The Short Textbook of Medial Microbiology ( $9^{\text {th }}$ Edition). Jaypee Brothers Medical Publisher Ltd. New Delhi, India, pp 164-209.

Harley, J.P. and Prescott, L.M. (2002). Laboratory Exercises in Microbiology. $5^{\text {th }}$ Edn. Mac Graw Hill, New York, 449 pp.

Horner, W.F.A. (1997), Preservation of fish by curing (drying, salting and smoking). In: Fish Processing Technology, Hall, G.M. $2^{\text {nd }}$ Editions. Blackie Academic and Professional, London, pp. 32 - 72.

Jeyaekaran, G., Granesan, P., Anadara, R., Jeya-Shakia, R. and Sukuna D. (2006). Quantitative and evaluative studies on the bacteriological quality of India white shrimp (Penaeus Indians) stored in dry ice. Journal of Food Microbiology, 23(6): 56 - 533.

Koffi-Nevny, R., Ouiha, T.S.T, Koussamon, M and Brou, B.K (2011). Chemical composition and lactic Microfloral of Ajuevan; A traditional Ivorian fermented fish condition Pak Journal of Nutrition, 10: 332-337.

Malik, A. and Ahmad, M (1994) Incidence of drug and metal resistance in $\mathrm{E}$. coli strains from sewage water and soil. Chemical and Environmental Research 3: 3 - 11

Martin, A.M. (1994). Fish Processing Biochemical Applications. Chapman and Hall, London, UK, pp 206 - 222.

N. C.C.L.S (2003) Methods for disk susceptibility tests for bacteria. National Committee for Clinical Laboratory Standards, $7^{\text {th }}$ ed., NCCLS Document M2-A7

Nestel, P.J.N. (2000). Fish oil and cardiovascular disease lipid and arterial function. American J ournal of clinical Nutrition 7: 228-231.

Ogunshe, A. A. and Olabode, P. O. (2009). Antimicrobial potentials of indigenous Lactobacillus strains on Gram-negative indicator bacterial species from Clarias gariepinus (Burchell, 1822): Microbial inhibition of fish-borne pathogens. African Journal of Microbiology Research 3(12), 870876.

Okoro, C.C., Aboaba, O.O. and Babajide, O.J. (2010). Quality Assessment of Nigeria Marine fish muttet (Liza falcipinnis) under different storage conditions. New York Science J ournal, 3(8): $21-28$

Olokor, J.O., Ihuahi, J.A., Omojowo, F.S., Falayi, B.A. and Adelowo, E.O. (2007). Handbook of Practical Fisheries Technology. Fisheries Technology Division (NIFFR). New Bussa, Niger State, Nigeria, pp 22 - 33.

Prescott, C. M, Harley, J. P and Klein, D. A (2002) Microbiology $5^{\text {th }}$ ed., McGraw Hill, New York, 1026pp

Sallam, K.I. (2007). Chemical, sensory and shelf life evaluation of sliced salmon treated with salts of organic acid. Food Chemistry, 101 (2): 592-600.

Sengor, G.F, Kalafatogu, H. and Gun, H. (2004). The determination of microbial floral water activity and chemical analysis in smoked mussel (Mytilus galloprorihcialis L.). Turkey Journal of Vitamins and Animal Science, 28: 793-797.

Sivertsvik, M., Jeksurd, W.K. and Rosnes, J.T. (2002). A review of modified atmosphere packaging of fish and fishery product - 
significance of microbial growth, activities and safety. International J ournal of Food Sciences and Technology, 37: 107-127.

Spanggard, B., Jorgenses, F. G. and Huss, H. H. (1993). Antibiotic resistance in bacteria isolated from three freshwater farms and an unpolluted stream in Demark. Aquaculture 115, 195-207.
Sutharshiny, S. and Sivashanthini, K. (2011). Total lipid and cholesterol content in the flesh of five important commercial fishes from around Jeffria Peninsular, Lanka. International Journal of Biological Chemistry, 6: $161-169$

Yagoub, S.O. and Ahmed, T.M. (2004). Pathogenic microorganisms in fresh water samples collected from Khartoum State. Journal of Bacteriology Research, 1(7): 87 88 